\title{
The 1909 Benavente (Portugal) earthquake: search for the source
}

\author{
J. Cabral • C. Moniz • J. Batlló • P. Figueiredo $\cdot$ J. Carvalho $・$ \\ L. Matias $\cdot$ P. Teves-Costa $\cdot$ R. Dias $\cdot$ N. Simão
}

Received: 30 May 2010/Accepted: 7 December 2011

(C) Springer Science+Business Media B.V. 2011

\begin{abstract}
The Lower Tagus River Valley has been affected by severe earthquakes comprising distant events, as in 1755, and local earthquakes, as in 1344, 1531, and 1909. The 1909 earthquake was located NE of Lisbon, near Benavente, causing serious damage and many losses. Mw 6.0 has been assessed for this earthquake and a reverse faulting focal mechanism solution has been calculated. Poor epicenter location, possible directivity and site effects, low fault slip rates, and the thick Cenozoic sedimentary cover make difficult correlation with regional structures. The focal mechanism indicates an ENE reverse fault as source, though it does not match any outcropping active structure suggesting that the event could have been produced by a blind thrust beneath the Cenozoic sedimentary fill. Hidden sources, inferred from seismic reflection data, are a possible NE structure linking the Vila Franca de Xira and the Azambuja faults, or the southern extension of the later. Evidence of surface rupturing is inhibited by the thick Holocene alluvial cover and the high fluvial sedimentation rate, though a slightly depressed area was identified in the Tagus alluvial plain $\mathrm{W}$ of Benavente which was investigated as possible geomorphic evidence of co-seismic surface deformation. A high-resolution seismic reflection profile was acquired across a $0.5 \mathrm{~m}$ high scarp at this site, and two trenches were opened across the scarp for paleoseismic research. Some deformation of dubious tectonic origin was found, requiring further studies.
\end{abstract}

Keywords Benavente earthquake $\cdot$ Seismotectonics $\cdot$ Lower Tagus Valley $\cdot$ Portugal

J. Cabral $(\bowtie) \cdot$ J. Batlló · P. Figueiredo · L. Matias · P. Teves-Costa · N. Simão Faculty of Sciences, IDL, Instituto Dom Luiz, Lisbon University, Lisbon, Portugal e-mail: jcabral@fc.ul.pt

C. Moniz $\cdot$ J. Carvalho $\cdot$ R. Dias

LNEG, Laboratório Nacional de Energia e Geologia, Amadora, Portugal

Present Address:

N. Simão

School of Environmental Sciences, University of Ulster, Coleraine, UK 